\title{
PEMBUATAN KULIT IMITASI UNTUK ATASAN SEPATU \\ DENGAN VARIASI JUMLAH BLOWING AGENT ADCM
}

\author{
Oleh : Soepranoto
}

\section{ABSTRACT}

Experiments of making PVC synthetic leather for shoe upper has been done by varying $A D C M$ blowing agent and the temperature of the middle coat layer coating process.

The composition used for each layer of the synthetic leather are :

Top coat (part)

: PVC emulsion 100, DOP 70, Epoxy oil 3, VM 1700/5 Stabilizer 5, $\mathrm{CaCO}_{3}$ filler 10, Stearic acid 1, Pigment 1.

Middle coat (part) : PVC emulsion 100, DOP 50, Epoxy oil 3, VM 1700/5 Stabilizer 5, $\mathrm{CaCO}_{3}$ filler 10 , ADCM blowing agent $2-6,{ }^{3}$ Activator (KK 42) 3, VS - 1031.

Base coat (part) : PVC emulsion 100, DOP 70, Epoxy oil 3, VM 1700/5 Stabilizer 5.

Temperature

$: 150-170^{\circ} \mathrm{C}$

variation

The supporting material used in this coating process is flannel fabric.

The product're 25 kinds of synthetic leather with $\pm 1 \mathrm{~mm}$ thickness and had been tested for physical properties such as : tensile strength, elongation at break, tear strength, adhesion strength between plastic layer and supporting textile fabric, flexing and stitch tear strength.

The optimum value of physical properties were achieved by the synthetic leather in which contain 6 parts of ADCM blowing agent, processed at $165^{\circ} \mathrm{C}$. It could be graded into the specification of Indonesian Industri al Standard number SII 1645 - 85 : Synthetic leather for shoe uppers. 
Campuran bahan dasar dengan bahan pembantu (kompon plastik) untuk masing-masing lapisan mempunyai susunan yang berbeda-beda.

Kulit imitasi sebagai bahan substitusi kulit tersamak diperkenalkan untuk pertama kalinya pada tahun 1963. Sebagai bahan baku yang dilekatkan pada permukaan bahan penguat dapat dipakai poli uretan (PU) atau polivinilklorida (PVC). Perkembangan terakhir menunjukkan bahwa kulit imitasi biasanya tersusun dari bahan penguat, busa polimer dan lapisan akhir. Macam dan jumlah lapisan dapat divariasi sesuai dengan tujuan penggunaannya.

Kulit imitasi untuk atasan sepatu dibuat mendekati kulit asli meskipun ada perbedaan yaitu bahwa masing-masing lapisan pada kulit imitasi kelihatan terpisah antara yang satu dengan lainnya secara nyata, sedangkan pada kulit asli lapisan lapisannya terlihat lebih kompak.

Kulit imitasi dari bahan baku PVC mempunyai beberapa sifat yang menguntungkan antara lain : mudah dibersihkan, sifat daya lenturnya tinggi, nilai rata-rata plastisitasnya luas, ketahanan degradasinyg dari sinar matahari baik, bisa adaptasi dengan perubahan modal, biaya produksi relatif tidak tinggi sehingga harganya relatif murah, dapat dibuat dengan bermacam macam warna dan rajah.

Menurut struktur pelapisan terhadap kain penguat, maka kulit imitasi dapat digolongkan menjadi tiga struktur pelapisan, yaitu :

a. Struktur satu lapis, yaitu pelapisan kain penguat dengan satu lapis bahan polimer,

b. Struktur dua lapis, yaitu pelapisan kain penguat dengan dua lapisan yang terdiri dari lapisan permukaan (top coat) dan lapisan dasar (base coat) dari bahan polimer.

c. Struktur tiga lapis, yaitu pelapisan kain penguat dengan tiga lapisan yang terdiri dari lapisan permukaan (top coat), lapisan tengah (middle coat) dan lapisan dasar (base coat) dari bahan polimer.

Untuk memperoleh sifat unggul yang mendekati kulit asli maka dalam pembuatan kulit imitasi disamping bahan dasar PVC emulsi sebagai bahan polimer diperlukan beberapa bahan pembantu yang dapat meningkatkan kwalitas atau sifat fisikanya, antara lain : stabilisator, bahan pemlastis (plasticizer), aktivator, blowing agent, pigmeri dan lain-lain.
Salah satu bahan penyusun pada lapisan tengah (middle coat) yang mempunyai peranan penting yaitu bahan pembentuk busa (blowing agent) yang salah satu jenisnya adalah azo dicarbonamide (ADCM).

Pemakaian ADCM dan suhu pemanasannya perlu diatur untuk memperoleh mutu produk yang terbaik. Pengaruh pemakaian ADCM dan pengaturan suhu pemanasan yang kurang tepat dapat berupa pengembangan busa (foam) yang tidak merata, memberikan ketahanan bengkuk dan ketahanan kikis yang rendah, menghasilkan kenampakan atau perabaan yang kurang baik

\section{MATERI DAN METODA}

Dalam percobaan ini dipergunakan bahan penguat berupa kain flanel dan bahan untuk masing-masing lapisan dengan komposisi berikut :

\begin{tabular}{l|c|c|c}
\hline \multicolumn{1}{c|}{ Bahan : } & $\begin{array}{c}\text { "Top } \\
\text { Coat" } \\
\text { (bagian) }\end{array}$ & $\begin{array}{c}\text { "Middle } \\
\text { Coat" } \\
\text { (bagian) }\end{array}$ & $\begin{array}{c}\text { "Base } \\
\text { Coat" } \\
\text { (bagian) }\end{array}$ \\
\hline PVC emulsi & 100 & 100 & 100 \\
Bahan pemlastis DOP & 70 & 50 & 70 \\
Epoxy oil & 3 & 3 & 3 \\
Stabilisator VM 1700/5 & 5 & 5 & 5 \\
(Ba Cd Zn Kompleks) & 10 & 10 & - \\
Bahan pengisi (filler) $\mathrm{CaCO}_{3}$ & - & $2-6$ & - \\
Blowing agent ADCM & - & 3 & - \\
Aktivator KK 42 & 1 & - & - \\
Asamstearat & 1 & - & - \\
Pigmen & - & 1 & - \\
Bahan pengontrol sel VS 103 & - \\
\hline
\end{tabular}

Percobaan dilaksanakan melalui beberapa tahapan yaitu :

1. Pra penelition : untuk mencari kondisi operasi yang tepat dengan mengatur suhu, lama pemanasan dan penentuan kadar DOP pada base coat.

Vol.IV.No.8-1988/1989 
Pada tahap ini diperoleh kondisi yang optimal yaitu suhu pemanasan top coat $140^{\circ} \mathrm{C}$ selama 4 menit, suhu pemanasan base coat $170^{\circ} \mathrm{C}$ selama 4 menit, suhu pemanasan middle coat divariasi : $150-170^{\circ} \mathrm{C}$ selama 4 menit, suhu finishing (pemanasan akhir) $200^{\circ} \mathrm{C}$ selama 2 menit dan kadar DOP dalam base coat terbaik adalah 70 bagian.

2. Tahap penelitian : merupakan tindak lanjut dari pra penelitian yaitu pembuatan kulit imitasi dengan variasi blowing agent $A D C M$ yang diatur berturut-turut mulai dari $2,3,4$, 5 dan 6 bagian serta variasi suhu pelapisan middle coat sebanyak 5 variasi pula, mulai dari 150 sampai $170^{\circ} \mathrm{C}$.

Urut-urutan proses pembuatan kulit imitasi adalah sebagai berikut :

a. Kain flanel sebagai bahan penguat di bersihkan permukaannya dari kotoran yang menempel sebelum dipakai.

b. Kompon untuk top coat yang sudah disiapkan, dilapiskan secara merata pada kertas embos sampai ketebalan 0,3 $\mathrm{mm}$. Kemudian dipanaskan pada suhu tetap $140^{\circ} \mathrm{C}$ selama 4 menit.

c. Kemudian diatasnya dilapiskan kompon middle coat sampai ketebalan $0,8 \mathrm{~mm}$ dan dipanaskan pada suhu yang dikehendaki antara $150-170^{\circ} \mathrm{C}$ selama 4 menit.

d. Terakhir dilapisi kompon base coat yang berfungsi sebagai perekat untuk kain penguat dengan ketebalan 1,0 $\mathrm{mm}$, kemudian ditutup dengan kain flanel sebagai bahan penguat dan selanjutnya dipanaskan pada suhu $170^{\circ} \mathrm{C}$ selama 4 menit.

Untuk menyempurnakan pengembangan gelembung foam pada middle coat dan proses pemasakan lapisan plastik PVC maka lembaran itu selanjutnya dipanaskan pada suhu yang lebih tinggi yaitu $200^{\circ} \mathrm{C}$ selama 2 menit.

Setelah dikeluarkan dari oven, lembaran kulit imitasi didinginkan untuk memisahkan kertas embosnya. Secara garis besar proses pembuatan kulit imitasi dapat dilihat pada skema berikut :

SKEMA PROSES COATING

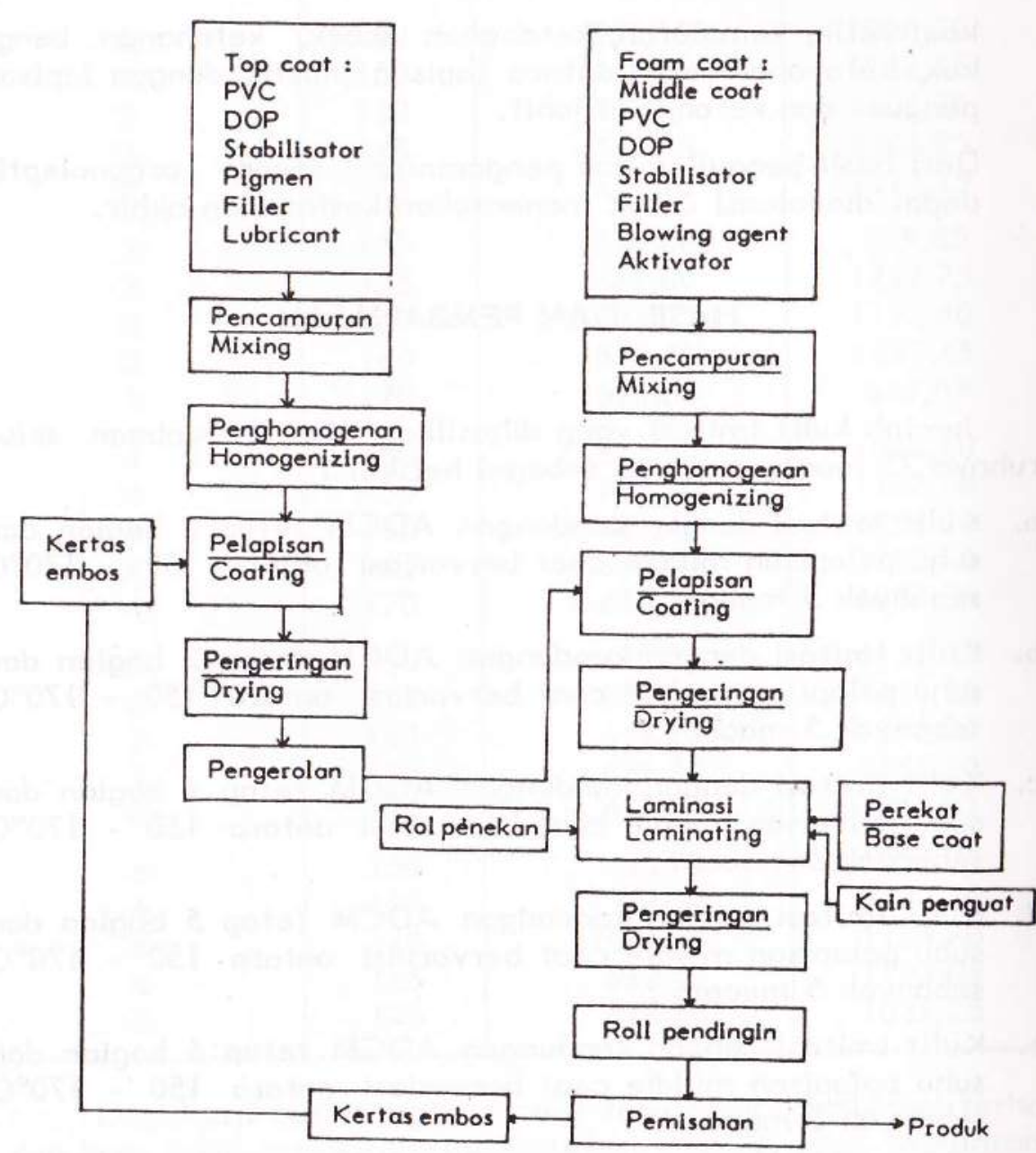


3. Tahap pengujian : dimaksud untuk menentukan sifat fisika dari produk kulit imitasi yang diperoleh.

Kulit imitasi hasil penelitian setelah didiamkan sekurangkurangnya 24 jam kemudian diuji sifat fisikanya meliputi uji :

kuat tarik, kemuluran, ketahanan sobek, ketahanan bengkuk, ketahanan rekat antara lapisan plastik dengan lapisan penguat dan ketahanan jahit.

Dari hasil pengujian dan pengamatan secara organoleptis dapat dievaluasi untuk menentukan kesimpulan akhir.

\section{HASIL DAN PEMBAHASAN}

Jumlah kulit imitasi yang dihasilkan dari percobaan seluruhnya 25 macam, terinci sebagai berikut :

a. Kulit imitasi dengan kandungan $A D C M$ tetap 2 bagian dan suhu pelapisan middle coat bervariasi antara $150-170^{\circ} \mathrm{C}$ sebanyak 5 macam;

b. Kulit imitasi dengan kandungan ADCM tetap 3 bagian dan suhu pelapisan middle coat bervariasi antara $150-170^{\circ} \mathrm{C}$ sebanyak 5 macam ;

c. Kulit imitasi dengan kandungan $A D C M$ tetap 4 bagian dan suhu pelapisan middle coat bervariasi antara $150-170^{\circ} \mathrm{C}$ sebanyak 5 macam ;

d. Kulit imitasi dengan kandungan $A D C M$ tetap 5 bagian dan suhu pelapisan middle coat bervariasi antara $150-170^{\circ} \mathrm{C}$ sebanyak 5 macam;

e. Kulit imitasi dengan kandungan ADCM tetap 6 bagian dan suhu pelapisan middle coat bervariasi antara $150-170^{\circ} \mathrm{C}$ sebanyak 5 macam.

Kulit imitasi yang dihasilkan tersebut keseluruhannya memiliki ciri ciri berikut : kain penguat dari flanel, tebal rata-rata 1 $\mathrm{mm}$ dan warna top coat merah.

Adapun hasil pengujian laboratorium terhadap sifat fisika dari masing-masing kulit imitasinya dapat dilihat dalam tabel 1 - 6 berikut :
Tabel 1 : Hasil pengujian kuat tarik

\begin{tabular}{c|c|c|c}
\hline $\begin{array}{c}\text { Jumlah ADCM } \\
\text { (bagian) }\end{array}$ & $\begin{array}{c}\text { Suhu } \\
\left({ }^{\circ} \mathrm{C}\right)\end{array}$ & $\begin{array}{c}\text { Arah melintang } \\
\left(\mathrm{N} / \mathrm{cm}^{2}\right)\end{array}$ & $\begin{array}{c}\text { Arah membujur } \\
\left(\mathrm{N} / \mathrm{cm}^{2}\right)\end{array}$ \\
\hline 2 & 150 & 655,10 & 1008,30 \\
2 & 155 & 666,50 & 1062,65 \\
2 & 160 & 702,25 & 1101,70 \\
2 & 165 & 740,65 & 1366,95 \\
2 & 170 & 639,10 & 1213,15 \\
3 & 150 & 628,80 & 919,85 \\
3 & 155 & 667,80 & 1212,75 \\
3 & 160 & 731,35 & 1152,40 \\
3 & 165 & 598,40 & 1099,65 \\
3 & 170 & 526,60 & 869,05 \\
4 & 150 & 612,30 & 1044,10 \\
4 & 155 & 786,30 & 1162,70 \\
4 & 160 & 661,40 & 1258,10 \\
4 & 165 & 630,50 & 1225,10 \\
4 & 170 & 618,60 & 1057,35 \\
5 & 150 & 620,25 & 1161,35 \\
5 & 155 & 532,80 & 1171,25 \\
5 & 160 & 649,85 & 1242,35 \\
5 & 165 & 699,60 & 1155,20 \\
5 & 170 & 629,30 & 994,45 \\
6 & 150 & 753,70 & 1096,95 \\
6 & 155 & 1131,30 & 1130,70 \\
6 & 160 & 1076,45 & 1153,60 \\
6 & 165 & 662,40 & 1223,05 \\
6 & 170 & 616,40 & 1032,25 \\
\hline
\end{tabular}

Dari hasil perhitungan secara treatment kombinasi terhadap kuat tarik ternyata nilai tertinggi untuk arah melintang adalah 1.131,3 N/mm dicapai oleh kulit imitasi dengan kombinasi kandungan ADCM 6 bagian pada suhu $155^{\circ} \mathrm{C}$. Sedangkan pada arah membujurnya adalah $1.366,95 \mathrm{~N} / \mathrm{cm}^{2}$ dicapai oleh kulit imitasi dengan kombinasi kandungan ADCM 2 bagian pada suhu $165^{\circ} \mathrm{C}$. 
Tabel 2 : Hasil pengujian kemuluran.

\begin{tabular}{|c|c|c|c|}
\hline $\begin{array}{l}\text { Jumlah ADCM } \\
\text { (bagian) }\end{array}$ & $\begin{array}{l}\text { Suhu } \\
\left({ }^{\circ} \mathrm{C}\right)\end{array}$ & $\begin{array}{c}\text { Arah melintang } \\
(\%)\end{array}$ & $\begin{array}{c}\text { Arah membujur } \\
(\%)\end{array}$ \\
\hline $\begin{array}{l}2 \\
2 \\
2 \\
2 \\
2\end{array}$ & $\begin{array}{l}150 \\
155 \\
160 \\
165 \\
170\end{array}$ & $\begin{array}{l}67 \\
68 \\
78 \\
80 \\
84\end{array}$ & $\begin{array}{l}35,5 \\
38,5 \\
45 \\
45 \\
34\end{array}$ \\
\hline $\begin{array}{l}3 \\
3 \\
3 \\
3 \\
3\end{array}$ & $\begin{array}{l}150 \\
155 \\
160 \\
165 \\
170\end{array}$ & $\begin{array}{l}74 \\
79 \\
93,5 \\
85 \\
93\end{array}$ & $\begin{array}{l}62 \\
63,2 \\
64 \\
61 \\
51\end{array}$ \\
\hline $\begin{array}{l}4 \\
4 \\
4 \\
4 \\
4\end{array}$ & $\begin{array}{l}150 \\
155 \\
160 \\
165 \\
170\end{array}$ & $\begin{array}{l}82 \\
92 \\
86 \\
81 \\
73\end{array}$ & $\begin{array}{l}46 \\
48 \\
52 \\
58 \\
44\end{array}$ \\
\hline $\begin{array}{l}5 \\
5 \\
5 \\
5 \\
5\end{array}$ & $\begin{array}{l}150 \\
155 \\
160 \\
165 \\
170\end{array}$ & $\begin{array}{l}81 \\
90 \\
73 \\
83 \\
74\end{array}$ & $\begin{array}{l}61 \\
64 \\
65 \\
71 \\
54\end{array}$ \\
\hline $\begin{array}{l}6 \\
6 \\
6 \\
6 \\
6\end{array}$ & $\begin{array}{l}150 \\
155 \\
160 \\
165 \\
170\end{array}$ & $\begin{array}{l}77 \\
73 \\
76 \\
72 \\
87\end{array}$ & $\begin{array}{l}48 \\
71 \\
72 \\
44 \\
40\end{array}$ \\
\hline
\end{tabular}

Dari hasil perhitungan secara treatment kombinasi terhadap kemuluran, nilai terendah arah melintang adalah $67 \%$ dicapai oleh kulit imitasi dengan kombinasi kandungan ADCM 2 bagian pada $150^{\circ} \mathrm{C}$. Pada arah membujurnya adalah $34 \%$ dicapai oleh kombinasi kandungan ADCM 2 bagian pada suhu $170^{\circ} \mathrm{C}$
Tabel 3 : Hasil pengujian ketahanan sobek

\begin{tabular}{|c|c|c|c|}
\hline $\begin{array}{l}\text { Jumlah } A D C M \\
\text { (bagian) }\end{array}$ & $\begin{array}{l}\text { Suhu } \\
\left({ }^{\circ} \mathrm{C}\right)\end{array}$ & $\begin{array}{l}\text { Arah melintang } \\
\qquad\left(\mathrm{N} / \mathrm{cm}^{2}\right)\end{array}$ & $\begin{array}{l}\text { Arah membujur } \\
\left(\mathrm{N} / \mathrm{cm}^{2}\right)\end{array}$ \\
\hline $\begin{array}{l}2 \\
2 \\
2 \\
2 \\
2\end{array}$ & $\begin{array}{l}150 \\
155 \\
160 \\
165 \\
170\end{array}$ & $\begin{array}{l}40,30 \\
41,60 \\
44,25 \\
41,80 \\
36,45\end{array}$ & $\begin{array}{r}37,50 \\
38,85 \\
+\quad 51,45 \\
45,55 \\
43,35\end{array}$ \\
\hline $\begin{array}{l}3 \\
3 \\
3 \\
3 \\
3\end{array}$ & $\begin{array}{l}150 \\
155 \\
160 \\
165 \\
170\end{array}$ & $\begin{array}{l}38,10 \\
43,90 \\
52,15 \\
37,10 \\
32,20\end{array}$ & $\begin{array}{l}44,55 \\
52,20 \\
49,90 \\
43,20 \\
42,35\end{array}$ \\
\hline $\begin{array}{l}4 \\
4 \\
4 \\
4 \\
4\end{array}$ & $\begin{array}{l}150 \\
155 \\
160 \\
165 \\
170\end{array}$ & $\begin{array}{l}34,40 \\
41,15 \\
47,50 \\
41,05 \\
40,70\end{array}$ & $\begin{array}{l}42,30 \\
46,95 \\
49,00 \\
53,95 \\
47,10\end{array}$ \\
\hline $\begin{array}{l}5 \\
5 \\
5 \\
5 \\
5\end{array}$ & $\begin{array}{l}150 \\
155 \\
160 \\
165 \\
170\end{array}$ & $\begin{array}{l}30,45 \\
35,85 \\
47,10 \\
43,25 \\
33,45\end{array}$ & $\begin{array}{l}35,45 \\
43,40 \\
51,25 \\
42,75 \\
41,15\end{array}$ \\
\hline $\begin{array}{l}6 \\
6 \\
6 \\
6 \\
6\end{array}$ & $\begin{array}{l}150 \\
155 \\
160 \\
165 \\
170\end{array}$ & $\begin{array}{l}36,25 \\
37,50 \\
41,25 \\
46,55 \\
30,75\end{array}$ & $\begin{array}{l}39,95 \\
41,80 \\
42,65 \\
46,80 \\
44,00\end{array}$ \\
\hline
\end{tabular}

Dari hasil perhitungan secara treatment kombinasi terhadap ketahanan sobeknya ternyata nilai tertinggi untuk arah melintang adalah $52,15 \mathrm{~N} / \mathrm{cm}^{2}$ dicapai oleh kulit imitasi dengan kombinasi kandungan ADCM 3 bagian pada suhu $160^{\circ} \mathrm{C}$. Untuk arah membujur nilainya adalah $53,95 \mathrm{~N} / \mathrm{cm}^{2}$ dicapai oleh kulit imitasi dengan kombinasi kandungan ADCM 4 bagian pada suhu $165^{\circ} \mathrm{C}$. 
Tabel 4 : Hasil pengujian ketahanan rekat antara lapisan plastik dan lapisan penguat.

\begin{tabular}{|c|c|c|c|}
\hline $\begin{array}{c}\text { Jumlah ADCM } \\
\text { (bagian) }\end{array}$ & $\begin{array}{l}\text { Suhu } \\
\left({ }^{\circ} \mathrm{C}\right)\end{array}$ & $\begin{array}{l}\text { Arah melintang } \\
\left(\mathrm{N} / \mathrm{cm}^{2}\right)\end{array}$ & $\begin{array}{l}\text { Arah membujur } \\
\left(\mathrm{N} / \mathrm{cm}^{2}\right)\end{array}$ \\
\hline 2 & 150 & \multirow{10}{*}{$\begin{array}{l}1,39 \\
1,79 \\
1,65 \\
1,32\end{array}$} & 0,89 \\
\hline 2 & 155 & & 1,16 \\
\hline 2 & 160 & & 1,43 \\
\hline 2 & 165 & & 0,90 \\
\hline 2 & 170 & & 0,77 \\
\hline 3 & 150 & & 0,99 \\
\hline 3 & 155 & & 1,15 \\
\hline 3 & 160 & & 1,41 \\
\hline 3 & 165 & & 2,04 \\
\hline 3 & 170 & & 1,33 \\
\hline 4 & 150 & 1,60 & 1,26 \\
\hline 4 & 155 & 1,87 & 1,72 \\
\hline 4 & .160 & 2,24 & 2,51 \\
\hline 4 & 165 & 1,68 & 1,14 \\
\hline 4 & 170 & 1,57 & 0,87 \\
\hline 5 & 150 & 1,45 & 0,915 \\
\hline 5 & 155 & 1,70 & 0,98 \\
\hline 5 & 160 & 1,77 & 1,41 \\
\hline 5 & 165 & 2,03 & 1,54 \\
\hline 5 & 170 & 1,12 & 1,43 \\
\hline 6 & 150 & 2,05 & 1,27 \\
\hline 6 & 155 & 2,32 & 1,49 \\
\hline 6 & 160 & 1,62 & 1,71 \\
\hline 6 & 165 & 1,18 & 1,67 \\
\hline 6 & 170 & 1,03 & 1,32 \\
\hline
\end{tabular}

Dari hasil perhitungan secara treatment kombinasi terhadap ketahanan rekat antara lapisan plastik dan lapisan penguat, nilai tertinggi pada arah melintang adalah sebesar 2,32 N/ $\mathrm{cm}^{2}$ dicapai oleh kulit imitasi dengan kombinasi kandungan ADCM 6 bagian pada suhu $155^{\circ} \mathrm{C}$, sedangkan pada arah membujur, nilainya adalah $2,51 \mathrm{~N} / \mathrm{cm}^{2}$ dicapai oleh kulit imitasi kombinasi kandungan ADCM 4 bagian pada suhu $160^{\circ} \mathrm{C}$.
Tabel 5 : Hasil pengujian kekuatan jahit.

\begin{tabular}{|c|c|c|c|}
\hline $\begin{array}{c}\text { Jumlah ADCM } \\
\text { (bagian) }\end{array}$ & $\begin{array}{l}\text { Suhu } \\
\left({ }^{\circ} \mathrm{C}\right)\end{array}$ & $\begin{array}{l}\text { Arah melintang } \\
(\mathrm{N} / 50 \mathrm{~mm})\end{array}$ & $\begin{array}{l}\text { Arah membujur } \\
(\mathrm{N} / 50 \mathrm{~mm})\end{array}$ \\
\hline $\begin{array}{l}2 \\
2 \\
2 \\
2 \\
2\end{array}$ & $\begin{array}{l}150 \\
155 \\
160 \\
165 \\
170\end{array}$ & $\begin{array}{l}451,5 \\
383,0 \\
427,5 \\
402,5 \\
337,5\end{array}$ & $\begin{array}{l}272,5 \\
272,5 \\
270,0 \\
268,5 \\
258,5\end{array}$ \\
\hline $\begin{array}{l}3 \\
3 \\
3 \\
3 \\
3\end{array}$ & $\begin{array}{l}150 \\
155 \\
160 \\
165 \\
170\end{array}$ & $\begin{array}{l}286,0 \\
300,0 \\
307,5 \\
347,5 \\
312,5\end{array}$ & $\begin{array}{l}242,0 \\
268,5 \\
298,5 \\
281,0 \\
242,5\end{array}$ \\
\hline $\begin{array}{l}4 \\
4 \\
4 \\
4 \\
4\end{array}$ & $\begin{array}{l}150 \\
155 \\
160 \\
165 \\
170\end{array}$ & $\begin{array}{l}338,5 \\
418,5 \\
421,0 \\
437,5 \\
412,0\end{array}$ & $\begin{array}{l}263,0 \\
276,0 \\
285,0 \\
295,0 \\
281,3\end{array}$ \\
\hline $\begin{array}{l}5 \\
5 \\
5 \\
5 \\
5\end{array}$ & $\begin{array}{l}150 \\
155 \\
160 \\
165 \\
170\end{array}$ & $\begin{array}{l}306,0 \\
382,5 \\
471,5 \\
373,5 \\
348,5\end{array}$ & $\begin{array}{l}241,5 \\
257,5 \\
266,0 \\
287,0 \\
277,0\end{array}$ \\
\hline $\begin{array}{l}6 \\
6 \\
6 \\
6 \\
6\end{array}$ & $\begin{array}{l}150 \\
155 \\
160 \\
165 \\
170\end{array}$ & $\begin{array}{l}309,0 \\
337,5 \\
311,5 \\
290,0 \\
249,0\end{array}$ & $\begin{array}{l}242,0 \\
262,5 \\
325,0 \\
307,5 \\
254,5\end{array}$ \\
\hline
\end{tabular}

Dari hasil perhitungan secara treatment kombinasi terhadap kuat jahit, nilai tertinggi pada arah melintang adalah sebesar $471,5 \mathrm{~N} / 50 \mathrm{~mm}$ dicapai oleh kulit imitasi dengan kombinasi kandungan $A D C M 5$ bagian pada suhu $160^{\circ} \mathrm{C}$, sedangkan pada arah membujur sebesar $325 \mathrm{~N} / 50 \mathrm{~mm}$ dicapai oleh kulit imitasi kombinasi ADCM 6 bagian pada suhu $160^{\circ} \mathrm{C}$. 
Tabel 6 : Hasil pengujian ketahanan bengkuk (Flexing).

\begin{tabular}{|c|c|c|c|c|c|c|}
\hline \multirow{2}{*}{$\begin{array}{c}\text { Kandungan } \\
\text { ADCM } \\
\text { (Bag) }\end{array}$} & \multirow{2}{*}{$\begin{array}{l}\text { Suhu } \\
\left({ }^{\circ} \mathrm{C}\right)\end{array}$} & \multicolumn{3}{|c|}{ Waktu Flexing } & \multirow{2}{*}{$\begin{array}{c}\text { Jumlah } \\
\text { Bekukan } \\
(*)\end{array}$} & \multirow[b]{2}{*}{$\mathrm{Ket}$} \\
\hline & & $\begin{array}{c}\text { Ulangan } \\
\text { I }\end{array}$ & $\begin{array}{l}\text { Ulangan } \\
\text { II }\end{array}$ & Rata $^{2}$ & & \\
\hline 2 & 150 & 24 jam & 24 jam & 24 jam & 436,364 & baik \\
\hline 2 & 155 & $24 \mathrm{jam}$ & 28 jam & 26 jam & 472.727 & baik \\
\hline 2 & 160 & 20 jam & 15 jam & 17 jam $30^{\prime}$ & 318.182 & retak \\
\hline 2 & 165 & 9 jam & 15 jam & 12 jam & 218.182 & retak \\
\hline 2 & 170 & 17 jam 38' & 15 jam & 16 jam $19^{\prime}$ & 296.667 & retak \\
\hline 3 & 150 & 24 jam $10^{\prime}$ & 17 jaim $30^{\prime}$ & 20 jam $50^{\prime}$ & 378.788 & retak \\
\hline 3 & 155 & 5 jam & 5 jam $10^{\prime}$ & 5 jam $5^{\prime}$ & 92.424 & retak \\
\hline 3 & 160 & 23 jam & 23 jam $30^{\prime}$ & 23 jam 15' & 422.727 & baik \\
\hline 3 & 165 & 5 jam & 4 jam $30^{\prime}$ & 4 jam $45^{\prime}$ & 86.364 & retak \\
\hline 3 & 170 & 6 jam $40^{\prime}$ & 5 jam 20' & 6 jam & 109.091 & retak \\
\hline 4 & 150 & 23 jam $40^{\prime}$ & 23 jam & 23 jam $20^{\circ}$ & 424.242 & baik \\
\hline 4 & 155 & 24 jam & 24 jam & 24 jam & 436.364 & baik \\
\hline 4 & 160 & 22 jam 20' & 23 jam 20 & 22 jam 50' & 415.152 & baik \\
\hline 4 & 165 & 4. jam & 4 jam $20^{\prime}$ & 4 jam $10^{\prime}$ & 75.758 & retak \\
\hline 4 & 170 & 11 jam 40' & 10 jam $40^{\prime}$ & 11 jam 10' & 203.030 & retak \\
\hline 5 & 150 & 24 jam & 24 jam & 24 jam & 436.364 & baik \\
\hline 5 & 155 & 7 jam $40^{\prime}$ & 4 jam $20^{\prime}$ & 6 jam & 109.091 & retak \\
\hline 5 & 160 & 11 jam 40' & 10 jam & 10 jam $50^{\prime}$ & 196.970 & retak \\
\hline 5 & 165 & 24 jam & 24 jam & 24 jam & 436.364 & baik \\
\hline 5 & 170 & 4 jam $30^{\prime}$ & 4 jam $30^{\prime}$ & 4 jam 30' & 81.818 & retak \\
\hline 6. & 150 & $-\quad 30^{\circ}$ & $-50^{\circ}$ & - $40^{\prime}$ & 12.121 & retak \\
\hline 6 & 155 & $-\quad 40^{\prime}$ & $-50^{\prime}$ & $-45^{\prime}$ & 13.636 & retak \\
\hline 6 & 160 & 3 jam $20^{\prime}$ & 3 jam & 3 jam 10' & 57.576 & retak \\
\hline 6 & 165 & 24 jam & 24 jam & 24 jam & 436.364 & baik \\
\hline 6 & 170 & 24 jam & 24 jam & 24 jam & 435.364 & baik \\
\hline
\end{tabular}
( $\left.{ }^{*}\right)$ Jumlah bengkukan $=\frac{\text { Waktu Flexing (menit) }}{66 \text { menit }} \times 20.000$ bengkukan
Dari hasil pengujian ketahanan bengkuk, dapat dipilih kombinasi antara kandungan ADCM dan suhu proses pemanasan middle coat yang menghasilkan kulit imitasi mempunyai ketahanan bengkuk memenuhi persyaratan SII 1645 - 85 yaitu yang mempunyai ketahanan bengkuk diatas $40.000 \times$ (dengan bekukan lebih dari $40.000 \times$ masih dalam keadaan baik, tidak rusak atau retak).

Dalam hal ini kulit imitasi yang masuk katagari baik atau terpisah dapat disebutkan kombinasi-kombinasi berikut :

a. Kulit imitasi dengan kandungan ADCM 2 bagian, suhu $150^{\circ} \mathrm{C}$;

b. Kulit imitasi dengan kandungan ADCM 2 bagian, suhu $155^{\circ} \mathrm{C}$;

c. Kulit imitasi dengan kandungan ADCM 3 bagian, suhu $160^{\circ} \mathrm{C}$;

d. Kulit imitasi dengan kandungan $A D C M 4$ bagian, suhu $150^{\circ} \mathrm{C}$;

e. Kulit imitasi dengan kandungan ADCM 4 bagian, suhu $155^{\circ} \mathrm{C}$;

f. Kulit imitasi dengan kandungan ADCM 4 bagian, suhu $160^{\circ} \mathrm{C}$;

g. Kulit imitasi dengan kandungan $A D C M 5$ bagian, suhu $150^{\circ} \mathrm{C}$;

h. Kulit imitasi dengan kandungan ADCM 5 bagian, suhu $165^{\circ} \mathrm{C}$;

i. Kulit imitasi dengan kandungan ADCM 6 bagian, suhu $165^{\circ} \mathrm{C}$;

j. Kulit imitasi dengan kandungan ADCM 6 bagian, suhu $170^{\circ} \mathrm{C}$.

Bila kelima jenis hasil pengujian dimuka yaitu : kuat tarik, ketahanan sobek, ketahanan rekat antara lapisan plastik dan lapisan penguat, kekuatan jahit dan kemuluran digambarkan dalam bentuk grafik, maka akan dapat diperoleh kurva-kurva yang masing-masing sifat fisikanya mempunyai nilai maksimal, ditunjukkan oleh puncak-puncak "peak" ataupun nilai minimum yang belum optimal (khusus pada kurva kemuluran).

Untuk kurva-kurva dengan dimensi yang sama yaitu kuat tarik, kuat sobek dan ketahanan rekat antara lapisan plastik dar lapisan penguat disatukan/dikumpulkan dalam satu grafik yaitu grafik 1.

Grafik 2 menunjukkan hubungan antara kuat jahit dengan variasi suhu, sedangkan grafik 3 menggambarkan hubungan antara kemuluran dan suhu.

Kalau dilihat secara keseluruhan, maka nilai-nilai optimal dari hasil pengujian kuat tarik, ketahanan sobek, ketahanan rekat antara lapisan plastik dan lapisan penguat dan kekuatan jahit yaitu puncak-puncak "péak" pada kurva' masing-masing terletak pada daerah suhu antara : $155-165^{\circ} \mathrm{C}$. Oleh karenanya sebagai jalan keluar untuk penyimpulan disusun suatu tabel prioritas dari beberapa macam kulit imitasi hasil penelitian yang memiliki ketahanan bengkuk baik, dari kombinasi terpipih yang terletak antara suhu $155-165^{\circ} \mathrm{C}$ sebagaimana terlihat pada tabel 7. 
Grafik 1. Kuat Tarik vs Suhu; Kuat Sobek ys Suhu ; Ketahanan Rekat vs Suhu

(2 bagian $A D C M$ ) ( 3 bayian $A D C M$ ) ( 4 bagian $A D C M$ ) ( 5 bagian $A D C M$ ) ( 6 bagian $A D C M$ )

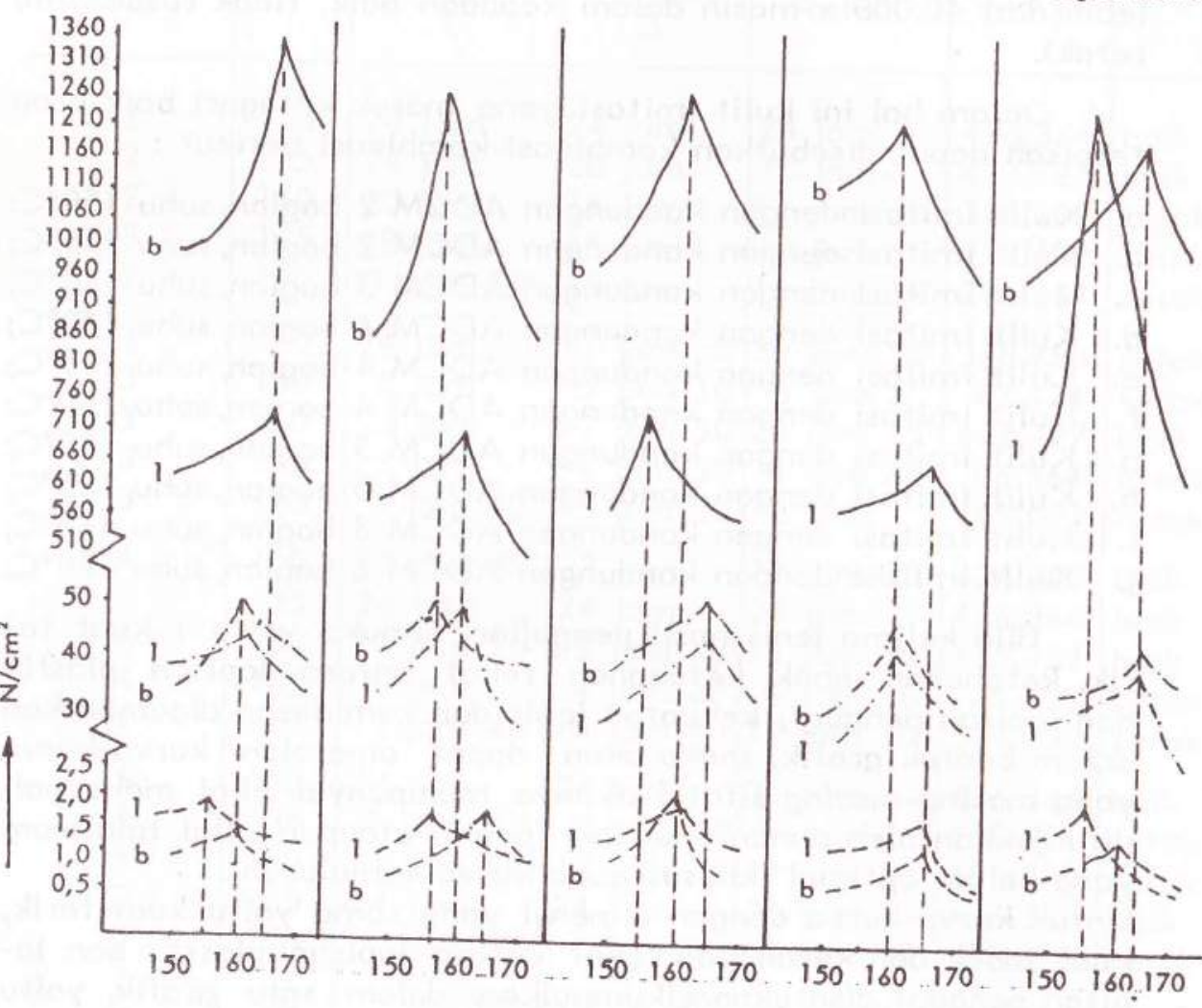

Grafik 2 Kuat Jahit vs Suhu

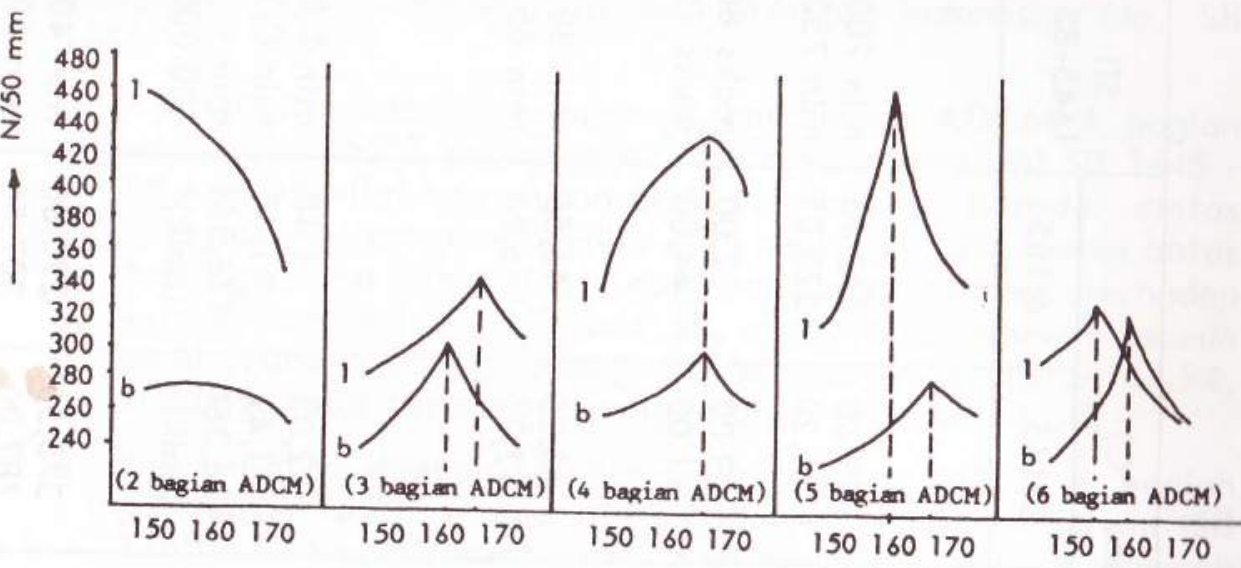

Grafik 3 Kemuluran vs Suhv

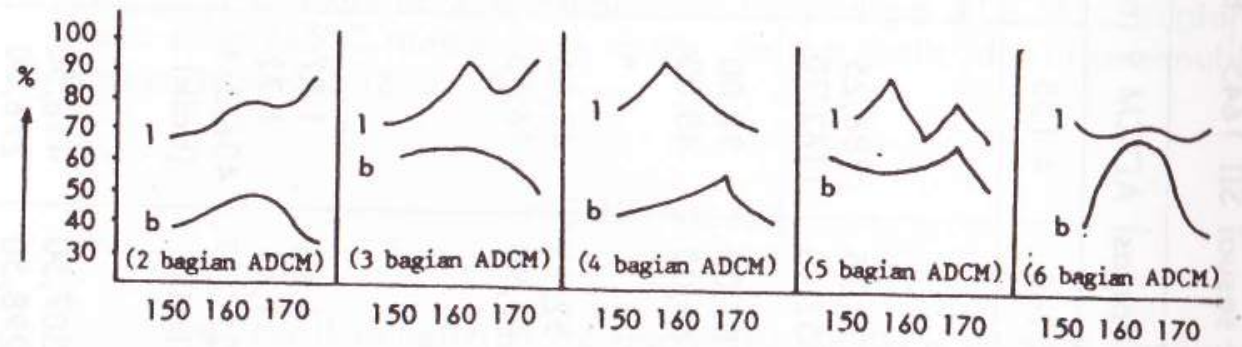

Keterangan : 1 = melintang; $b=$ membujur.

melintang; $b=$ membujur. $\longrightarrow$ suhu $\left({ }^{\circ} \mathrm{C}\right)$
: kuat tarik, $-\ldots .-$ : kuat sobek, $\ldots-$ : ketahonan rekat 


\begin{tabular}{|c|c|c|c|c|c|c|c|}
\hline \multicolumn{2}{|c|}{$\begin{array}{c}n \\
\infty \\
\vdots \\
\vdots \\
\substack{1 \\
0}\end{array}$} & $\begin{array}{l}\text { 읏유 } \\
\qquad \frac{c}{E} \\
\text { E }\end{array}$ & 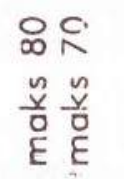 & $\begin{array}{l}\text { 의 } \\
. \subseteq \\
\qquad \frac{E}{E}\end{array}$ & 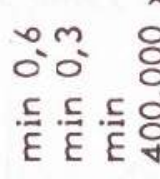 & & $\begin{array}{l}\text { 웅 } \\
\text { 들 }\end{array}$ \\
\hline \multirow{3}{*}{ 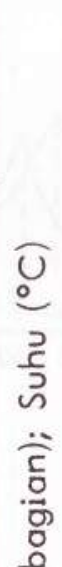 } & $\frac{n}{0}$ & 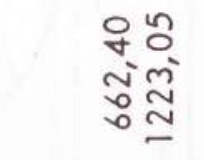 & $\begin{array}{l}88 \\
\text { Nंy }\end{array}$ & 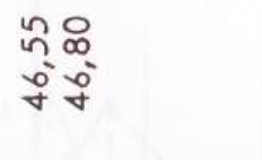 & 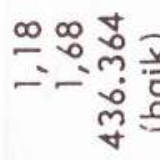 & & 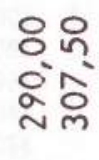 \\
\hline & $\begin{array}{l}n \\
\check{c} \\
i\end{array}$ & $\begin{array}{l}000 \\
00 \tilde{n} \\
a \mathfrak{n}= \\
0=\end{array}$ & $\begin{array}{l}\text { 으 } \\
\text { miñ }\end{array}$ & 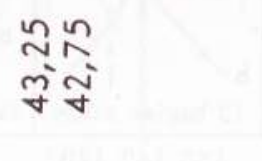 & 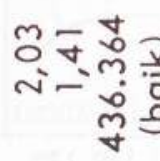 & & $\begin{array}{l}\text { 응 } \\
\text { ñî } \\
\text { ñ }\end{array}$ \\
\hline & $\frac{ㅇ}{\dddot{0}}$ & 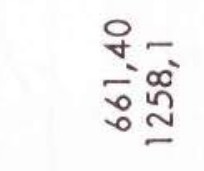 & 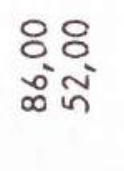 & $\begin{array}{l}\simeq 8 \\
\text { ‡ia }\end{array}$ & 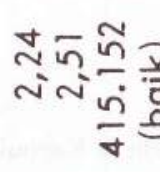 & & 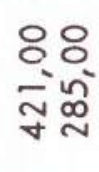 \\
\hline $\begin{array}{l}\sum_{U}^{0} \\
0 \\
4\end{array}$ & $\frac{n}{n}$ & 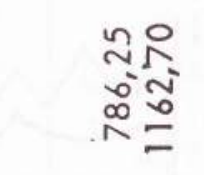 & 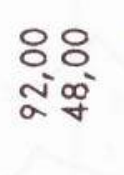 & 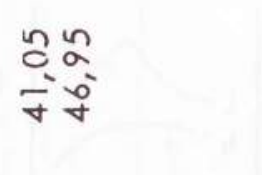 & 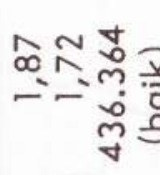 & & 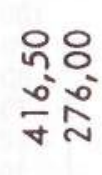 \\
\hline 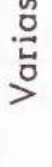 & $\frac{O}{\ddot{m}}$ & $\begin{array}{l}\text { mo } \\
\text { m̃ñ } \\
\text { m }\end{array}$ & $\begin{array}{l}\text { 용ㅁ } \\
\text { ஸ் }\end{array}$ & $\begin{array}{l}\text { nO } \\
\text { Nivg }\end{array}$ & 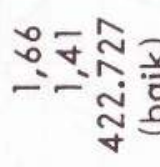 & & 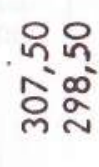 \\
\hline & $\frac{n}{i}$ & 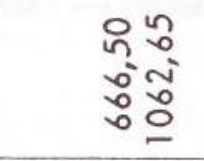 & 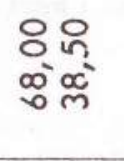 & 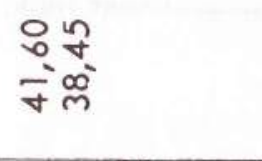 & \begin{tabular}{l}
$8 \cong N$ \\
N-N \\
\multirow{N}{N}{}
\end{tabular} & & 유 \\
\hline & ? & 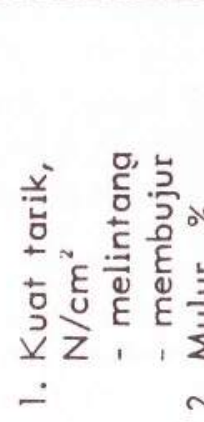 & 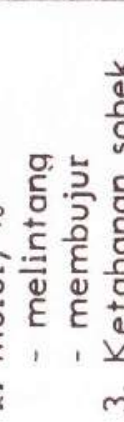 & 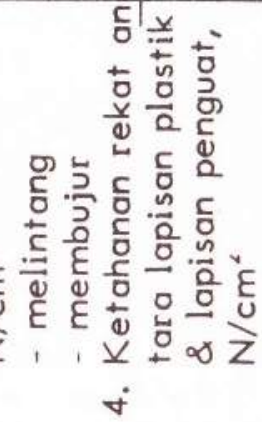 & 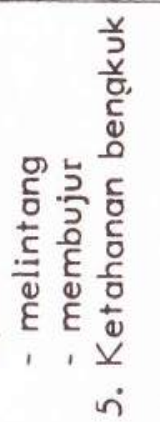 & 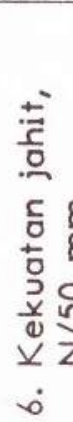 & 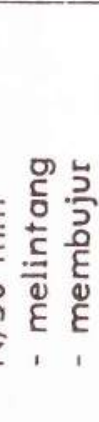 \\
\hline
\end{tabular}

Pada tabel 7 terlihat ada 2 macam Kulit Imitasi yang mutunya dapat memenuhi Standar Industri Indonesia No. SII $1645-85$ yaitu :

a. Kulit imitasi dengan kombinasi kandungan ADCM 4 bagian pada suhu $155^{\circ} \mathrm{C}$ semua sifat fisikanya memenuhi SII 1645 85 kecuali nilai kemuluran arah melintang berada diatas persyaratan maksimum yaitu bila dihitung 15\% diatas batas tertinggi, dan bila ditinjau dari urutan prosentase terhadap jumlah contoh (sampel) pada SII, maka nilai tersebut berada pada urutan ke $57 \%$, sedang SII berada pada urutan $67,5 \%$, sehingga nilai tersebut dianggap dapat memenuhi SII.

b. Kulit imitasi dengan kombinasi kandungan ADCM 6 bagian pada suhu $165^{\circ} \mathrm{C}$ semua sifat fisikanya juga memenuhi SII 1645 - 85 kecuali kuat tarik arah melintang sedikit dibawah persyaratan yaitu $+5,4 \%$ dibawah batas minimum, tetapi urutan prosentasenya sama dengan SII, yaitu $20 \%$.

Dengan demikian dari kedua macam kulit imitasi tersebut, kulit imitasi dengan kombinasi kandungan ADCM 6 bagian pada suhu $165^{\circ} \mathrm{C}$ mempunyai mutu paling baik dan memenuhi persyaratan SII $1645-85$.

\section{KESIMPULAN}

Dari hasil penelitian ini dapat disimpulkan sebagai berikut:

1. Kulit imitasi yang sifat fisikanya dapat memenuhi SII 1645 85 ada 2 macam yaitu :

a. Kulit imitasi dengan kombinasi kandungan ADCM 4 bagian dan suhu proses middle coat $155^{\circ} \mathrm{C}$.

b. Kulit imitasi dengan kombinasi kandungan ADCM 6 bagian dan suhu proses middle coat $165^{\circ} \mathrm{C}$.

2. Kulit imitasi dengan kombinasi kandungan $A D C M \quad 6$ bagian dan suhu proses middle coat $165^{\circ} \mathrm{C}$ mempunyai sifat fisika yang terbaik.

3. Formulasi kompon PVC bagi lembaran kulit imitasi untuk atasan sepatu yang terbaik dan memenuhi persyaratan SII 1645 - 85 adalah sebagai berikut : 
Top coat

Middle coat

Base coat

: PVC emulsi 100 bagian, DOP 70 bagian, Epoxy oil 3 bagian, Stabilisator ( Vm 1700/5) 5 bagian, filler $\mathrm{CaCO} 3$ aktif 10 bagian, asam stearat 1 bagian, pigmen 1 bagian.

PVC emulsi 100 bagian, DOP 50 bagian, Epoxy oil 3 bagian, Stabilisator ( $\mathrm{Vm}$ 1700/5) 5 bagian, filler $\mathrm{CaCO} 3$ aktif 10 bagian, blowing agent $A D C M$ bagian, aktivator (KK42) 3 bagian, VS 1031 bagian.

PVC emulsi 100 bagian, DOP 70 bagian, Epoxy oil 3 bagian, Stabilisator ( $\mathrm{Vm}$ 1700/5) 5 bagian.

\section{DAFTAR PUSTAKA}

1. CIBA GEIGY," Manual of PVC - Additives", Marienburg omosh, Jerman Barat, 1971.

2. DEPARTEMEN PERINDUSTRIAN, SII 1645 - 85," Standar Mutu Kulit Imitasi Untuk Atasan Sepatu", 1986

3. GUPTA, RK., "Plaistics Coating and Lamination Technoloay and Plastics Directory", Small Business Publication; Delhi.

4. GUPTA, RK., "Hand Book of Small Scale Plastics Industries". Small Business Publication, Delhi.

5. MARK HERMAN F.Et.al " Leather Like Materials".

in Encyclopedia of Polymer Science and Technology Interscience, New York, 8, 1968, Page 210 - 230.

6. Mc GRAW-HILI,," Modern Plastics Encyclopedia", Volume 59, Number 1982 - 1983 Ed I.

7. SHIMIZU, K., "Synthetic Leather", Japan Plastic Age, April 1971, Page 38-42.

8. SITI ROCHANI, Ir., dkk, "Penggunaan Plastisator DOP Untuk Meningkatkan Mutu Kulit Imitasi dari PVC "Proy. PPKKP 1984 - 1985.

9. SUGANDI M., KUN HARIMURTI., " Lembaran Plastik dan Kegunaannya" Pusat Pramuteknik Petrokimia, Pertamina, Jakarta. 1982.

10. SOEKENI SOEDIGDO \& SOEDIGDO P," Pengantar Cara Sta tistik Kimia" Penerbit ITB, 1977 